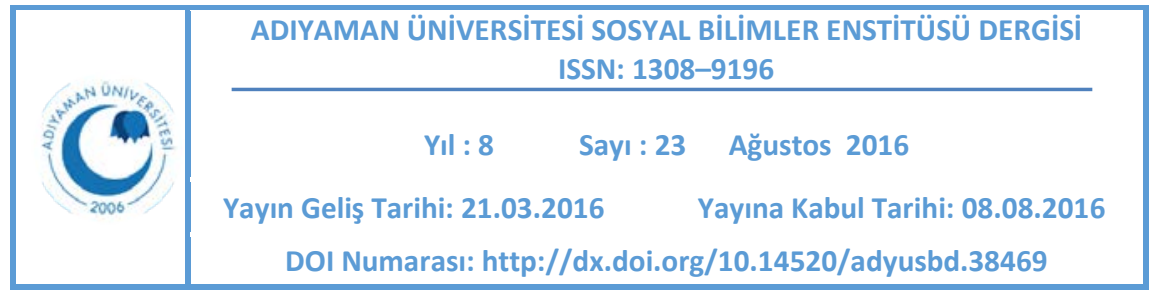

ADIYAMAN MÜZESI KALIP YAPIMI KÂSELERi

\title{
Hatice ÇORBACI*
}

\begin{abstract}
$\ddot{O} z$
Atina'da i.Ö. 3. yüzyılın ortalarından sonra görülmeye başlayan Megara kâseleri, Hellenistik Dönem'in tipik seramik türlerindendir. Masa üstü kaplarından biri olarak bilinen bu kâseler yaklaşık yarım küre biçiminde, kulpsuz ve kaidesizdir. Pahalı metal kapların topraktan yapılmış ucuz örnekleri olarak kalıpla yapılmış olan kâselerin dış yüzlerinde kabartma bezeme bulunmaktadır. Tüm Hellenistik merkezlerde bulunan bu ürün siyahtan kırmızıya ve kahverengiye kadar farklı tonlarda sırlanmıştır. Hellenistik Dönem'in ortalarında Terra Sigillata olarak anılan kırmızı sırlı yeni seramik türleri üretilmiştir. Sigillatalar yoğun olarak bulundukları bölgelere göre gruplara ayrılmaktadır. Adıyaman Müzesi'nde bulunan kalıp yapımı beş kâse Hellenistik Dönem Megara Kâseler'in devamı olarak Doğu Sigillataları A grubunda üretilmiş kâselerdir. Kâselerden biri Tille Höyük'ten, diğerleri Adana ve Adıyaman civarından gelme olup satın almadır. Çalışmanın amacı kâselerin özelliklerini benzerleriyle kıyaslayıp tarihlemektir. Kâseler genel olarak i.Ö. 1. yüzyıla önerilebilir.
\end{abstract}

Anahtar Kelimeler: Adıyaman Müzesi, Megara Kâseleri, kalıp yapımı kâseler, Doğu Sigillata A, Antakya.

${ }^{*}$ Yrd.Doç.Dr. Adıyaman Üniversitesi, Fen Edebiyat Fakültesi, hcorbaci@adiyaman.edu.tr 


\title{
THE MOLD MADE BOWLS IN ADIYAMAN MUSEUM
}

\begin{abstract}
Megarian bowls, which began to be seen in Athens in the second half of $3^{\text {rd }}$ century $B C$, are typical ceramic type of the Hellenistic Period. Known as one of the tablewares, these bowls are nearly hemispherical, without handles and foot. Molded with clay to be cheaper than metalwork, these bowls' exterior surfaces are decorated with relief. These bowls, found in all Hellenistic centers, were glazed with different tones ranging from black, red and to brown. In the midst of the Hellenistic Period, new ceramic types called Terra Sigillata, which were red-glazed, were produced. Sigillata wares are classified into various groups according to their regions. Five molded bowls in Adiyaman Museum belong to the category of Eastern Sigillata A as a continuation of Hellenistic Period Megarian bowls. One of the bowls comes from Tille Höyük while others, having been purchased, come from the vicinities of Adana and Adıyaman. The aim of this study is to compare the features of bowls with similar bowls and date. These bowls could be dated to the $1^{\text {st }}$ century $B C$.
\end{abstract}

Keywords: Adlyaman Museum, Megarian Bowls, Moldmade Bowls, Eastern Sigillata A, Antakya (Antioch).

\section{GiRiş}

Hellenistik Dönem'de Akdeniz havzasında yaygın olarak kullanım bulan kalıp yapımı kâseler (Megara Kâseleri), Klasik Dönem'in kantharoslarının yerini alan içki kaplarıdır. Topraktan ve kalıpla yapılmış, yaklaşık yarım küre biçimli, kulpsuz ve ayaksız olan bu kâselerin dış yüzünde kabartma bezeme bulunmaktadır. Metal ürünlerin taklidi olan kâseler, metal izlenimi vermek üzere (Anlağan, 2000: 30) siyaha, ayrıca kırmızıdan kahverengiye kadar değişik tonlarda boyanmışlardır. Atina'da i.ö. 240-220 civarında (Rotroff, 1982: 10), Batı Anadolu'da ise en erken üretildiği merkezlerden biri olarak bilinen Bergama'da i.Ö. 2. yüzyııın başında ortaya çıkmışlardır (De Luca, 1968: 123, 125).

i.ö. 2. yüzyııın ortalarında, doğulu çömlekçilerin masa üstü kaplarına uyguladıkları yeni bir teknik ortaya çıkmışır. Kap yüzeyini tamamen kırmızı sır 
ile kaplama esasına dayanan bu teknik kısa sürede moda olmuş, daha sonra Roma İmparatorluğu eyaletlerinde de yaygınlaşmıştır (Jones, 1950: 172). Bu tekniğin ortaya çıkışıyla beraber piyasada yeni kap türleri de görülür. Geç Hellenistik ve Erken Roma Dönemi'nde revaçta olan bu kaplar Terra Sigillata olarak adlandırılmaktadır (Dragendorff, 1895: 3). Megara kâseleri bu dönemlerde yarım küre biçimini kısmen korumakla beraber daha küçük ölçüde, yüzeysel ve daha az bezeme çeşidiyle yaşamını sürdürmüştür.

\section{1. Terra Sigillatalar}

Terra Sigillata olarak adlandırılan kaplar kırmızı astarlı, kalıpla yapılmış, kabartma bezemeli veya bezemesiz olup Doğu ve Batı Sigillataları olarak iki grupta incelenmektedirler. Batı Sigillataları İtalya, Fransa, İspanya, Almanya civarında yaygındır. Batı Sigillataları Avrupa içlerinde, Doğu Sigillataları Doğu Akdeniz yerleşimlerinde üretilmiştir.

Parlak kırmızı astarlı kapları niteleyen Terra Sigillata terimi ilk kez 19. yüzyılda Dragendorf (1895: 19) tarafından kullanılmıştır. Dragendorf, antik dönemde kullanılmamış bir terim olan Terra Sigillata terimini “Arretin vazoları" isminin yerine kullanmıştır. İnce kırmızı sırlı, üzeri bezeli, çok iyi pişirilmiş ve çok çeşitli formları bulunan bu kaplar, keskin ve köşeli profilleri ile metal örnekleri taklit etmişlerdir (Dragendorf, 1895: 19). Roma topraklarının genişlemesiyle Roma seramiği eyaletletlere yayılıp, buralardaki yerel seramikle de karışmıştır (Dragendorf, 1895: 18). Bu nedenle Dragendorf Batı Sigillataları olarak bilinen bu türü sınıflama gereği duymuştur.

Doğu Sigillataları ile ilgili olarak Plinius, (NH 35, 160, 161) bu parlak kırmızı astarlı seramiği "Vasa Samia" olarak adlandırmış, Samos, Pergamon ve Tralleis'te üretilen kırmızı sırlı seramikten bahsetmiştir. Zahn (1904: 430), Priene buluntularıyla ilgili araştırması sonucunda özelliklerine göre Samos malları ve 
Pergamon malları olarak farklı iki grup üzerinde durmuştur. Daha sonra Loeschke (1912: 344), Çandarlı'da tespit ettiği sigillatları yerel üretim olarak belirlemiştir. Waage (1948: 4), Antakya materyalini incelemiş ve sigillataları Geç Hellenistik Pergamen ve Erken Roma Pergamen olarak ayırmıştır. Tarsus malzemesini çalışan Jones (1950: 173) da bu gruplamayı tercih etmiştir. Pergamen olarak adlandırılan bu mallar yerel Bergama üretimlerinden doku ve renk olarak farklı olup, Bergama'da yoğun olarak ele geçmiş olmasından dolayı bu adı alan sigillatalardır.

Samaria'da araştırmalar yapan Kenyon (1957: 281, 282), Doğu Sigillatalarını (ES: East Sigillata), gruplamış ve isimlendirmiştir. Kenyon, Pergamen malları olarak anılan grup için Doğu Sigillataları A (ESA), Samos malları olarak anılan grup için Doğu Sigillataları B (ESB) ve üretim yeri bu iki gruba oranla daha iyi tahmin edilebilen Çandarlı malları için Doğu Sigillataları C (ESC) terimlerini kullanmıştır. Hellström (1965: 28), Doğu Sigillataları A ve B gruplarını da kendi içinde I ve II olarak sınıflandırmıştır. Daha sonra araştırmacılar tarafından farklı gruplamalar yapılmış ise de genel olarak Kenyon'un gruplaması kabul görmektedir.

Doğu Sigillataları A grubu formları esas olarak tabak, fincan ve kâse gibi açık kaplardır. Bu kapların en erken formları erken yerel malların etkilediği (Waage 1948: 10) Hellenistik karakterli formlar olup, İ.Ö. 1. yüzyıl başında formlarda gelişim görülmektedir (Hayes, 2008: 16). Açık formlu Doğu Sigillataları A ve B mallarında sırlama, bir toprak eriyiğin içine önce kabın bir kısmını, sonra 180 derece çevirip diğer yarısını batırarak çift daldırma şeklinde yapılmıştır (Hayes, 2008: 11).

Iliffe (1936: 5), sigillataların köklerinin doğuda bulunduğunu, İtalya'daki üretimin Küçük Asya'daki benzerlerinin etkisi olmadan yapılamayacağını belirmekte ve kırmızı seramiğin ne zaman popüler olduğunu ve kimlerin icat ettiğini sorgulamaktadır. Iliffe, Batı ve Doğu buluntularıyla ilgili tarihsel bir kıyaslama 
yaparak Doğu örneklerinin daha erken olduğundan ve Filistin Müzesi Kolleksiyonları́nda çoğu Filistin'e ait sigillataların bulunduğundan söz etmektedir. Waage (1948: 10) de, yerel seramik olarak Suriye Filistin bölgesinin Erken Demir Çağı'ndaki en karakteristik seramiğinin parlak kırmızı astarlı oldukça kaba mallar olduğunu belirtmektedir. Hellenistik dönem içlerine kadar yaşamını sürdüren kırmızı renk, Levant'ta çömlekçilerin tercihi olmuştur. Burada yerel kırmızı çömlekçiliğin yanı sıra Yunanistan'dan gelen malların siyah rengini taklit eden başarısız çömlekçiler de bulunmaktadır (Waage, 1948: 10). Kırmızı seramiğin kökeni olarak Suriye-Filistin önerilerinin yanı sıra Urartular'ın kırmızı renkli ve parlak görünümlü lüks mallarından da söz edilebilir. Bu mallar Urartular'da madenciliğin etkisinde, özellikle Urartu kalelerindeki resmi çömlekçi atölyelerinde üretilmiştir. I.Ö. I. bin yılda tamamen Urartu’ya özgü olarak görünen bu kırmızı sırlı mallar bir süre sonra önemini kaybetmiştir (Sevin, 2003: 237, 238). Aynı şekilde Hitit seramik sanatının öne çıkan özelliği olan kırmızı renkli parlatılmış malları da saymak gerekir. Bu mallar kendinden önceki dönemlerin devamı olarak en üst seviyesine Eski Hitit Çă̆ı'nda erişmiştir (Genç, 2005: 117).

Kalıpla yapılan ve Hellenistik Dönemin kalıp yapımı yarım küre kâselerinin (Megara Kâseleri) devamı olan kâseler, Tarsus, Antakya, Hama ve diğer SuriyeFilistin yerleşimlerinde çok miktarda bulunmaktadır (Hayes, 2008: 16). Kenyon'un (1957: 281 ve devamı) Samaria'da form 20 ile grupladığı Megara Kâseleri, başka merkezlerde farklı numaralarla belirlenmiştir. Örneğin Filistin seramik grubunda 158 (Lapp: 1961, 143), Gindaros'ta 24 ve devamı olan kâseler 24a formu ile temsil edilmektedir (Kramer, 2004: 177, 176). Hayes (1985/1986: 24, 25), Megara Kâselerini form 24 ile bu kâselerin devamı olan sigillataları form 25 ile belirlemiştir. 


\section{2. Kronoloji}

Waage'nin (1948: 25) Antakya ESA'ları için önerdiği tarih i.Ö. 150'den biraz öncesidir. Levant'taki son buluntular bu malların ortaya çıkışları için bu tarihi onaylamaktadır. Bu tarih Ashdod, Beyrut, Paphos, Shiqmona, Tel Anafa ve Corinth buluntularıyla desteklenmiş olup, yaklaşık i.Ö. 160-130 arasını kapsamakta (Hayes, 2008: 19, dipnot 45) ve bazı merkezlerde üretim İ.S. 3. yüzyıl içlerine kadar sürebilmektedir (Kramer, 2004: 174, dipnot 373). Weinberg (1992: 17), Hayes'in geç kâseler (Form 25) için verdiği i.S. 2. yüzyılın ilk yarısı tarihini Tel Anafa için çok geç olarak nitelemektedir. Kırmızı sırlı mallar ve kalıp yapımı kâseler Tel Anafa'da i.ö. 2. yüzyılın üçüncü çeyreğinde görülmüş ve i..Ö. 80 civarına Hellenistik yerleşimin sonuna kadar sürmüş, ancak i̇.S. 1. yüzyılın içlerine kadar yaşamını sürdürmüştür. (Weinberg, 1992: 12).

Kırmızı sırlı kapların İtalya'ya girişi ise i.ö. 40-30 civarında olmuştur. Bu kaplar İtalyan çömlekçiler arasında çok tutulan mallar olarak yaygınlaşmış, İtalya'dan Gaul ve İspanya'ya ve Rhein bölgesine yayılmıştır (Hayes, 2008: 42 ve dipnot 8). İtalyan malları aynı zamanda doğu eyaletlerine de satılmıştır. Illk ihracat az miktarda ve i..Ö. 15- 10 yıllarında yapılmış, Ege pazarlarında her zaman bulunan bu mallar farklı İtalyan üretim merkezlerinden ithal edilmiş ve i.Ö. 30/20 ve i.s. 100+ yılları arasında Doğu Sigillata mallarının üretildiği merkezlerde de taklit edilmiştir (Hayes, 2008: 43).

\section{YÖNTEM}

Kültür ve Turizm Bakanlığı Kültür Varlıkları ve Müzeler Genel Müdürlüğü ve Adıyaman Müzesi Müdürlüğü izniyle Adıyaman Müzesi'nde bulunan beş kâse ile ilgili olarak yapılan envanter araştırmalarına göre kâselerin biri Tille Höyük'ten gelme, diğerleri Adana ve Adıyaman civarından gelme olup satın almadır. Kâselerin çizim ve fotoğraflama işlemleri dışında yapıldığı toprağa ait doku ve 
renk özellikleri, kâsenin sırına ait renk özellikleri, ölçüleri ve kâse tanımlarını içeren bir katalog çalışması yapılmıştır. Bu araştırmada kâseleri hem birbiriyle hem de benzer özellikler taşıyan başka örneklerle biçim, bezeme, toprak ve renk özellikleriyle kıyaslayarak olası üretim merkezleri ve tarihleme açısından bir sonuca ulaşılmaya çalışılmıştır.

\section{BULGULAR}

Hellenistik Dönemde Suriye' de en büyük seramik üretim merkezi olarak Antakya gösterilmektedir (Kramer, 2004: 137). Bu dönemde Suriye ve Filistin çok yakın ticaret ilişkisi içinde olduğundan Antakya malları bu bölgede çok yaygındır. Megara Kâseleri'nin geç tipine ait olan kâseler Yakın Doğu'da Megara Kâseleri'nden daha fazla talep edilmiştir. Geç kâselerin büyük bir kısmı bu bölgenin oldukça kuzeyinde Antakya'da bulunmuştur (Weinberg, 1992: 19). Crowfoot (1957: 272), yaptıkları araştırmalara göre Samaria'daki Megara kâselerinin metropolden (Antakya) ithal edilmiş olduğu sonucunun ortaya çıktığını, Kramer (2004: 140, 179) ise Gindaros'ta hem Megara Kâseleri'nin hem de ESA buluntularının yapısal olarak Antakya örnekleri ile büyük oranda benzeştiğini belirtmektedir. Kramer 'e (2004: 174) göre ESA'ların ortaya çıktığı bölge Suriye-Filistin çevresindeki geniş alandır. Yayılım alanı ise esasen Suriye Filistin, doğuya doğru Fırat'ın batı yakasına kadar, bunların dışında Kuzey Afrika ve Girit, Kıbrıs, Küçük Asya batı kıyılarında az, Yunanistan'da çok az, kuzey batı bölgelerinde tek tük bulunabilir. Malfitana'nın, Doğu Akdeniz'de Doğu Terra Sigillataları yayılımı araştırmasına göre Suriye'de ESA buluntuları tüm seramik buluntuları arasında en fazla sayıda olandır. Bu buluntular Suriye'nin kuzey batı kısmında yoğunlaşmaktadır (Malfitana, 2002: 147). Malların çoğu kuzey sahili ve civarında bulunmakla birlikte en doğudaki yerleşimlere (Dura Europos) kadar gitmiştir. Kilikia'da en fazla ESA buluntusu Tarsus'ta ele geçmiş, bunu daha az sayıda ancak kaliteli olarak Anamur takip etmiştir. Bu mallar olasılıkla Kıbrıs veya 
Suriye kaynaklarından beslenmekte ve güney sahillerinden daha batıya doğru azalarak yayılmaktadır (Malfitana, 2002: 143). Kramer (2004: 175), geniş bir alana dağılmış, aynı özelliklere sahip ve yüksek kalitedeki ESA mallarının en azından üretimin başlangıcında sadece bir üretim merkezinden çıkmış olabileceğini savunmaktadır. Slane (1997: 272), Tel Anafa ve Hama buluntusu ESA'ların orijinal kaynağının Kuzey Suriye'de olduğunu ve Asi Nehri boyunca yayıldığını belirtmektedir. Antakya yakınındaki bir başka Merkez olan Jebel Khalid'deki kalıp yapımı örnekler için de kaynak olarak Antakya gösterilmektedir (Jackson-Tidmarsh, 2013: 331, 332). Tarsus ve Antakya arasındaki alan da olası üretim bölgesi olarak anılmaktadır (Kenrick, 2013: 2). ESA'ların geniş yayılımı ve üretimi için bu güne kadar kesin bir kaynak merkez belirlenememiştir. Hayes (2008: 13), Antakya, Hama ve Tel Anafa olası geniş üretim bölgesi olarak önerilen alan içinde görülse de, kimyasal ve bilimsel analizlerin Kilikya'nın doğu sahil kısmını veya Hatay sahilini, belki de günümüzde özellikle İskenderun'un kuzey bölgesini işaret ettiğini belirtmektedir.

Waage (1948: 29, 30), Antakya Megara kâselerini erken (i..Ö. son üç yüzyıl) ve geç (i.S. ilk iki yüzyıl) yerel kâseler olarak ayırmıştır. Erken ve geç örnekler arasında bazı açılardan bozulmalar söz konusudur. Megara kâselerinde bordür, gövde ve madalyon bezemeleri bulunur. Zengin bezeme motifleri kâse yüzeyini doldurur. Kabartmalar keskin hatlıdır. Ortalama h: $8 \mathrm{~cm}$, çap: $15 \mathrm{~cm}$ 'dir. Yarım küre biçimli bu kâselerin Antakya'daki en yaygın tipi dışa dönük dudaklı kenar tipidir (erken kâselerin özellikleri için Waage, 1948: 29). Waage (1948: 30), geç kâselerin özelliklerini şu şekilde özetlemiştir: “Antakya geç kâseleri ile erken kâseleri arasında yapı olarak bir değişiklik yoktur, genellikle daha sert, daha ince ve renklerde soluk devetüyünden daha fazla görülen açık kahverengiye kadar farklı tonlardadır. Geç örnekler, erken örnekler gibi her zaman katkısızdır. Eğer kâsenin dokusu sert ise pürüzlü, yumuşak dokulu ise pudra gibi dökülebilir. Daha geç kâseler bazen daha kalın ve yumuşaktır. Sır daha ince ve görünüşte 
daha sıkı, kavuniçi-kırmızıdan çok koyu kahve-kırmızıya bir eğilim vardır. Sırın dış kısmı genellikle soyulmuş olup, kâsenin yüzeyinde mat, açık kırmızı bir tabaka kalır. Biçim ise erken örneklere göre pek çok parçada daha küçük ve bodurdur. Daha geç kâseler konik biçime yakındır. Bezeme ögeleri gittikçe basitleşir ve azalır. Bezeme bölümleri yoktur, bordürler sadece geçiş örneklerinde bulunur. Erken kâselerin erken safhasının büyük ve gösterişli yaprak motifleri geç örneklerde seyrek ve küçük motifler haline gelmiştir. Ayrıca geç kâselerin erken örneklerindeki bezeme motiflerinin sıkışık olarak düzenlenmesi terkedilmiş, küçük, sıradan bitkisel motifler geniş aralıklarla kâse yüzeyine yerleştirilmiştir". Basit bitkisel motiflerin hemen ardından figürlü sahneler de gerilemiştir. Kabartmalar da alçak ve basit kontur çizgileriyle belirlenmiştir (Kramer, 2004: 177). Genellikle bordür ve hatta bordür çizgisi de yoktur. Dipte madalyon halkası bulunur, ancak genellikle madalyon bezemesi yoktur.

Kilikya'nın doğusunda Hellenistik Dönemde seramik üreten bir diğer önemli merkez Tarsus'tur. Tarsus'ta Megara kâseleri az, sigillata olarak anılan kabartmalı kâseler daha fazladır. Tarsus'un kili devetüyü, devetüyü kırmızı, kavuniçi kırmıı veya kırmızı olup, inceden orta dereceye kadar değişen tanecikler ve biraz mika içermektedir (Jones, 1950: 177). Sır ise sert yüzeyli iyi kaliteli bir kırmıı olabilir veya çok düzgün olmayan dalgalı bir tabaka olabilir. Kazı yerlerinde i.Ö 2. yüzyılın ortalarından Erken İmparatorluk dönemi başlarına kadar bulunurlar (Jones, 1950: 172). Antakya ve Tarsus kâseleri hemen hemen aynı biçim ve bezeme tarzı gösterirler. En önemli fark Antakya kâselerinin dokusu katkısız iken, Tarsus kâselerinin dokusunun tanecikli ve az mikalı olmasıdır.

Adıyaman Müzesi kâselerinin biri Tille Höyük'ten gelme diğerleri Adana ve Adıyaman civarından gelme olup satın almadır. Kâselerin dokusu katkısızdır ve mika bulunmamaktadır. Kil renkleri biri pembemsi devetüyü, diğerleri açık 
devetüyü, sır ise koyu kırmızı kahverengi, kırmızımsı kahverengi, koyu kırmızı kahverengi, açık kırmızı kahverengi ve kiremit kırmızısı tonlarındadır. Kâselerin doku ve renk özellikleri Antakya kâseleri özelliklerine uymaktadır. Katalogdaki 1 ve 2 no'lu kâseler diğer kâselere göre daha derin ve erken kâselere daha yakındır. Kâse kenarları dışa doğru açılmaktadır. Her iki kâsede de bordür frizi ve bezemesi yoktur, bu özellik bu kâseleri geç kâselere yaklaştırır.1 no'lu kâsenin yunus balıkları erken örneklerdeki dolgun ve hareketli yunuslara göre oldukça incelmiştir. Kâsenin gövdesi erken örneklerde görülmediği tarzda bitişik zakkum dallarıyla bezenmişken, 2 no'lu kâse gövdesi dört kez tekrarlanan palmiye ve akantus yapraklarıyla bezenmiştir. Her iki kâsede geç kâselere (Weinberg, 1992: 19) ait özellik olarak tek geniş kuşak bezemesi bulunmaktadır. Her iki kâsede de erken kâselerde görülen madalyon halkası içinde rozet bezemesi vardır. Dolayısıyla 1 ve 2 no'lu kâseler hem erken hem geç dönem özellikleri taşıdığından bu kâseler erken tiplerden geç tiplere geçişi sağlayan örnekler olarak nitelendirilebilir.

2 no'lu kâse Tille Höyük'ten gelmedir. Tille Höyük, Adıyaman Kâhta ilçesinin 30 km. doğusunda, Fırat'ın batısında yer alan günümüzde Atatürk Baraj suları altında kalmış olan bir höyüktür. D. French Tille Höyük'te üç tabaka tespit etmiştir. 3. ve en genç tabaka üç evre, 2. tabaka üç evre, en eski olan 1. tabaka 2 evreden oluşmaktadır (French, 1984: 245). Tille Höyük'te erken Ortaçağ katının hemen altında başlayan Hellenistik tabakada bazı ince, kırmızı mallara ait parçalar ve özellikle kalıp yapımı kabartmalı mallar bulunmuştur. Bu mallar ortalama İ.Ö. 1. ve I.S. 1. yüzyıllara tarihlenmektedir (French, 1982: 417).

2 no'lu kasenin hem biçim hem de gövde bezemesi açısından bir benzeri Tel Anafa kâseleri arasındadır. Cornell (1997: 410), Tel Anafa kâselerinde çok yaygın olan bezeme tarzının madalyondan yükselen uzun, gür yapraklar olduğunu belirtip, Hama örnekleriyle kıyaslamaktadır. 2 no'lu kasenin bir diğer benzeri ise 
günümüzde Atatürk Baraj suları altında kalan höyüklerden biri olan Tille Höyük'ün yakınında Fırat Nehri kıyısında Lidar Höyük'te ele geçmiştir (Gerber, 1996: 304, 315, Abb. 1, 11). Form veren bir Doğu Sigillata A kâse parçası üzerinde 2 no'lu kasenin palmiye bezemesi bulunmaktadır. Lidar buluntusu kâsenin biçimi de 2 no'lu kase ile aynıdır. Lidar Höyük'ten bir diğer kâseye ait dip parçası üzerinde madalyon halkası etrafına sıralanmış palmiye dallarına ait bezeme yer almaktadır. Madalyonun ortasında ise yıldız biçiminde, oval, kenar ve orta çizgileri belirtilmiş içi kabarık 4 yapraktan oluşan bir rozet yer almaktadır. Bu rozet biçimi Antakya kâselerinin karakteristik bezemelerindendir (Waage, 1948: fig. 15: 18, fig. 16: 18). Aynı rozet bezemesi Gindaros DSA parçaları arasında yer almakta ve Kramer tarafından bir Antakya kâse parçasıyla örneklenmektedir (Kramer, 2004: 189, 107, Tafel 83). Lidar Höyük'te araştırmalar yapan Gerber (1996: 304), bu iki sigillata parçasını ithal mallar olarak belirtmektedir.

Geçiş dönemine ait ilk iki kasenin yüksekliği $6.6 \mathrm{~cm}$ ve $6.4 \mathrm{~cm}$, diğerlerinin yüksekliği $5.6 \mathrm{~cm}$ ve $4.8 \mathrm{~cm}$, hepsinin çapı ortalama $12.4 \mathrm{~cm}$ 'dir. Ölçülerden de anlaşılacağı üzere kâseler geç dönem özelliği olarak gittikçe kısalmış ve yayvanlaşmıştır.

3 no'lu kâse dip kısmı en düz kâse olarak geç örneklere aittir. Bu tipte dip düzleşip, cidar dışa doğru yayvanlaşmış ve kenar kısmı da dışa doğru açıımışır. Bordür ve madalyon rozeti yoktur. Kâsenin orta kısmının biraz altında alışıımadık bir kabartma çizgi bulunmaktadır. 3 no'lu kâsede bulunan yunus balıkları da 1 nolu kâsedeki gibi oldukça incelmiştir.

Weinberg (1992: 12,16), Philedelphia'da satın alınmış, şu anda Missouri Üniversitesi Müzesi'nde bulunan ve Hama'dan (Suriye) geldiği belirtilen bir kâseyi, Princeton Üniversitesi Art Museum'da bulunan bir kâse ile bir bezeme motifi açııından kıyaslamaktadır. Her iki kâsedeki "feuilles-cordiformes" olarak 
anılan kalp biçimli yaprak motifine Hama'da pek çok kâsede rastlandığını, ayrıca Kıbrıs, Tarsus, Antakya, Tel Anafa ve Samaria'da da ele geçtiğini belirtip, ölçüleri aynı olan her iki kâseyi de Suriye-Filistin grubuna vermektedir.

Princeton kâsesinde çanak kuşağı üzerinde önce ince, sonra daha geniş (ana kuşak) iki bezeme kuşağı daha vardır. Ince kuşakta bezeme motifi olarak kalp biçimli yapraklar ("feuilles-cordiformes") ve 3 no'lu kâsede bulunan altar motifi yer almaktadır. Weinberg, bu yukarı ve aşağı kıvrık çift volüt başlıklı altar motifi için Tel Anafa'da ele geçen bir kâse parçasındaki benzerini örnek vermektedir (Weinberg, 1992: 16, dipnot 8 ve 5). Bu kâse parçası için Tel Anafa kâselerini inceleyen Cornell (1997: 411, PI. 3: MB 44), “ionik bir başlıkla taçlandırılmış altar olabilecek mimari bir element" ifadesini kullanmıştır.

Bir diğer altar veya sütun motifi için Weinberg (1992: 18, fig. 7) Kraus'un (1951: 12, dipnot 94: Abb.5: 2, no. 16) tanıttığı Mainz'da bulunan bir kâsedeki sütun motifini örnek vermekte ve Princeton kâsesindeki sütun motifi ile aynı olduğunu vurgulamaktadır. Kraus, Mainz'daki kâsede yukarı ve aşağı kıvrılmış çift volütlü başlığı olan küçük bir sütunun yer aldığı oldukça ince açık kırmızı renkli hamurlu bir kâsenin doğuda Küçük Asya atölyelerinden birine ait olması gerektiğini, bunun Suriye'ye ait olabileceğini belirtip, Waage'nin bir Antakya örneğiyle kıyaslamakta ve i.Ö. 1. yüzyııı ikinci yarısına, olasılıkla yaklaşık i.Ö. 30-25 yıllarına ait olabileceğini belirtmektedir. Kraus (1951: 12, Abb.5: 2, no. 15), aynı kil ve sır özelliklerine sahip Mainz'daki ikinci bir kâseyi de aynı atölyeye vermektedir. Mainz'daki kâselerle biçimleri aynı olan, altar motifinin yer aldığı 3 no'lu kâse yukarıda belirtilen örnekler çerçevesinde Antakya üretimlerine yaklaşmaktadır.

4 no'lu kâsenin benzeri Adana Müzesi'nde bulunmaktadır (Taş, 2010: fig.41, K15). Kâse hem biçim, hem de geç dönemde görülen içi boş madalyon halkasından yükselen, aralıklı olarak yerleştirilmiş 4 palmiye dalı bezemesiyle 
aynıdır. 4 no'lu kâsede olduğu gibi Adana kâsesinde de eğrilik vardır. Olasılıkla aynı atölyedendir.

5 no'lu kâse biçim olarak oldukça yayvan ve kenar kısmı da düzleşmiş olarak, hem "koşan köpek" hem de palmet motifleriyle Antakya'nın geç kâse örneklerindendir (Waage, 1948: fig. 16: 10 ve 19). "Koşan köpek" (Kossatz, 1990: 13, MB 28) olarak adlandırılan motif, Efes- Ion atölyelerinde genellikle bordür motifi olarak çok yaygın kullanım bulmuştur. Bu motif dalga motifi olarak da adlandırmaktadır (Laumonier, 1977: 73, 9300). Kasenin bezeme motiflerinden biri olan meşe palamutu (pelit), Hesiodos'un (Works and Days: 230-235) tanımıyla yeryüzünün bolluk bereket sembollerinden biridir. Bu meyve Efes Artemis heykelinde görüldüğü üzere Artemis'in sembollerindendir (https://tr.wikipedia.org/wiki/Artemis, 2006). Heykelin üzerinde bulunan diğer sembollerin yanısıra meşe palamutu dizisinden oluşan gerdanlığı, Artemis'in sadece ormanlar tanrıçası değil, Farnel'in (1896: 533) tanımıyla tüm yabani ağaçların kime ait olduğunu ve onun yarattıklarının kimin meyveleri tarafından beslendiğini gösteren bir semboldür. Antik Dönemde meşe palamutu motifi mücevherlerde, Uşak Müzesi Lidya Karun Hazinelerinde görüldüğü gibi özellikle kolye bezemelerinde çok sevilen bir motiftir (https://tr.wikipedia.org/wiki/Karun_Hazinesi, 2006).

\section{SONUÇ}

Adıyaman Müzesi'ndeki kalıp yapımı kâseleri, yarım küre biçimli Hellenistik Dönem'in Megara Kâseleri'nin devamı olarak yarım küre biçiminden cidarları dışa açılan kâse biçimine doğru bir gidiş göstermektedir. Erken kâselerin cidarları geç kâselere göre daha dik, geç kâselerin cidarları ise dışa eğimlidir. Aynı zamanda kâse boylarının kısaldığı da görülmektedir. Bordür bezemesi ve ilk iki kâse haricinde madalyon bezemesi de yoktur. Megara Kâseleri'nin karakteristik geniş ayalı akantus yapraklarının yerini madalyon halkasından 
yükselen ince palmiye ve zakkum dalları gibi önceki örneklere göre daha sıradan bezeme veya seyrek motifler almıştır. Bezeme özensiz, kabartmalar alçak kabartma şeklinde olup, 3 no'lu kâsede olduğu gibi bazı bezemeler zorlukla seçilebilmektedir. Bu özellikler Adıyaman Müzesi kalıp yapımı kâselerini Hellenistik Dönem'in geç safhasına önermemizi sağlamaktadır. Kâselerin yapı ve renk özellikleri de Kuzey Suriye-Filistin Bölgesi'nin en büyük seramik üretim merkezi olarak anılan Antakya Kâseleri ile benzeşmektedir. Waage (1948: 4), Geç Hellenistik için geç i.Ö. 2. yüzyıldan Augustus Dönemi'ne kadar, Erken Roma için Augustus Döneminden İ.S. 2. yüzyılın erken dönemine kadar olan aralığı vermektedir. Katalogdaki 1 ve 2 no'lu kâseler diğer kâselere göre daha derin ve madalyon bezemesine sahip olmalarından dolayı geç örneklere geçişi sağlayan örneklerdir. 2 no'lu kâse Tille Höyük buluntusu olup, kazı başkanı tarafından Hellenistik katta bulunan bu tür kaplar için i.Ö. 1. ve i.S. 1 yüzyıl aralığı önerilmektedir (French, 1982: 417). 3 no'lu kâse ise Weinberg'in Princeton kâsesini kıyasladığı ve Kraus'un (1951: 12) Antakya özelliklerini taşıdığını belirttiği Mainz'daki kâseler ile aynı form ve altar motifi bezemesi taşıdığından Kraus'un verdiği tarih olan i.ö. 1. yüzyılın ikinci yarısına ait olmalıdır. 4 ve 5 no'lu kâseler bu grup içinde en kısa ve yayvan örnekler olarak en geç örneklerdir. Kâseler genel olarak i̇.Ö. 1. yüzyıl içine ve sonuna önerilebilir.

\section{KATALOG}

(S: sır, T: toprak, Ö: ölçüler, a. ç: ağız çapı, k: kalınlık, fig. figür, PI. plate, çizimler: 1/1.Sinem Aslan).

1. Env. No. 4543 , resim 1a, 1b, şekil 1

Buluntu Yeri: Adıyaman civarı

S: İç-dış koyu kırmızı kahverengi, alt kısmı daha açık devetüyü, burada sır aşınmış

T: açık devetüyü (soluk bej), sert, ince, katkısız, 
Ö: h: $6.6 \mathrm{~cm}$ (iç h: $6.1 \mathrm{~cm}$ ), a.ç: $12.4 \mathrm{~cm}, \mathrm{k}: 0.3-0.5 \mathrm{~cm}$

Kâsenin Durumu: Ağız kısmında küçük bir çentik dışında kâse tamdır. Kenar kısmında düzensiz çark izleri, içinde de çark izleri vardır. Yer yer kireç kaplıdır.

Biçim: Düz dipli, dışa doğru düz bir şekilde genişleyen yayvan bir kâsedir. Kenar kısmı dudağa doğru şişkince açılmaktadır.

Bezeme: Kâsenin kenar kısmını gövdeden ayıran kabartma çizgi kenardaki pek çok çark iziyle karışmıştır. Kabartma çizginin altında peş peşe sıralanmış yunus balığı motifi yer almaktadır. Dipte silik bir madalyon halkası vardır. Tüm gövde madalyon halkasından yunuslara kadar uzanan ince, dışa doğru açılmış, seyrek yapraklı ve birbirine bitişik olarak düzenlenmiş zakkum (?) dallarıyla bezenmiştir. Gövde üzerindeki bu dallar bazı yerlerde madalyon halkasının içine girecek şekilde özensizdir. Madalyon bezemesi olarak yıldız biçiminde ince, oval, kenar ve orta çizgileri belirtilmiş içi kabarık 6 yapraktan oluşan bir rozet yer almaktadır.

\section{Karşılaştırma}

Biçim: Cornell 1997: PI.3: MB 32; Kramer 2004: Tafel 82, ESA 82; gövde bezemesi: (zakkum ?) dalları: Jones 1950; fig. 139: 311 ve fig. 140 C; Waage 1948; fig. 13: 16, 17, fig. 16: 5; Christensen 1971: fig. 50: 39-41; fig. 52: 55a-b; Kramer 2004: Tafel 82, ESA 82; Taş 2010: fig. 28, K9, fig. 30, K10; yunuslar: Christensen 1971: fig. 51: 46a, fig. 55: 84 ve fig. 62: 20; Jones 1950: 138: 305, 142: C; madalyon bezemesi: Waage 1948: fig. 14: 21 (burada 6 yapraklı), fig.15: 18 (burada aynı yapraklar dörtlü) ve fig.16: 18; Christensen 1971: fig. 50: 31a, fig. 51: 49; fig. 52: 57e, fig. 56: 103a, fig. 58: 121a, 122, 123, 119a; fig. 62: 18; Çorbacı 2012; 84: resim 6, çizim 4 (burada 5 yapraklı); Bounni 1978: fig. 36: 20; Cornell 1997: PI. 1: MB 1, PI. 2: MB 24; Jones 1950: PI. 139: 314; Vessberg 1956: 
fig. 27: 10; Çorbacı 2007: 179, 2; 183, 2; Reisner 1924: 72a, 73c, e; Kramer 2004, Tafel 83 ESA 107 (burada dört yapraklı); Taş 2010: Levha XXVI K10

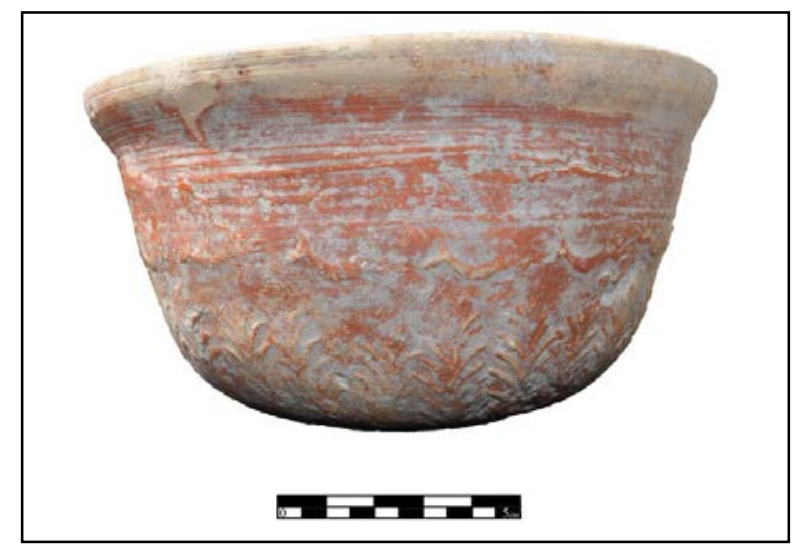

Resim 1a

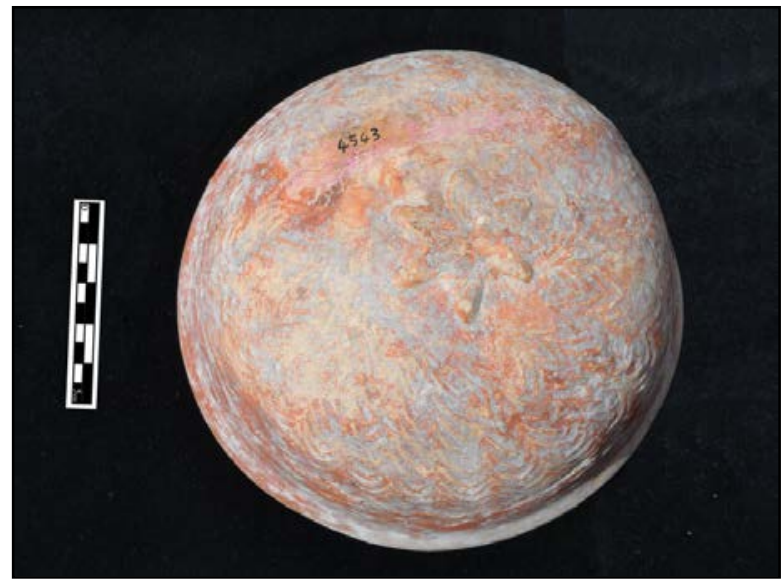

Resim 1b

Adıyaman Üniversitesi Sosyal Bilimler Enstitüsü Dergisi, Yıl: 8, Sayı: 23, Ağustos 2016 


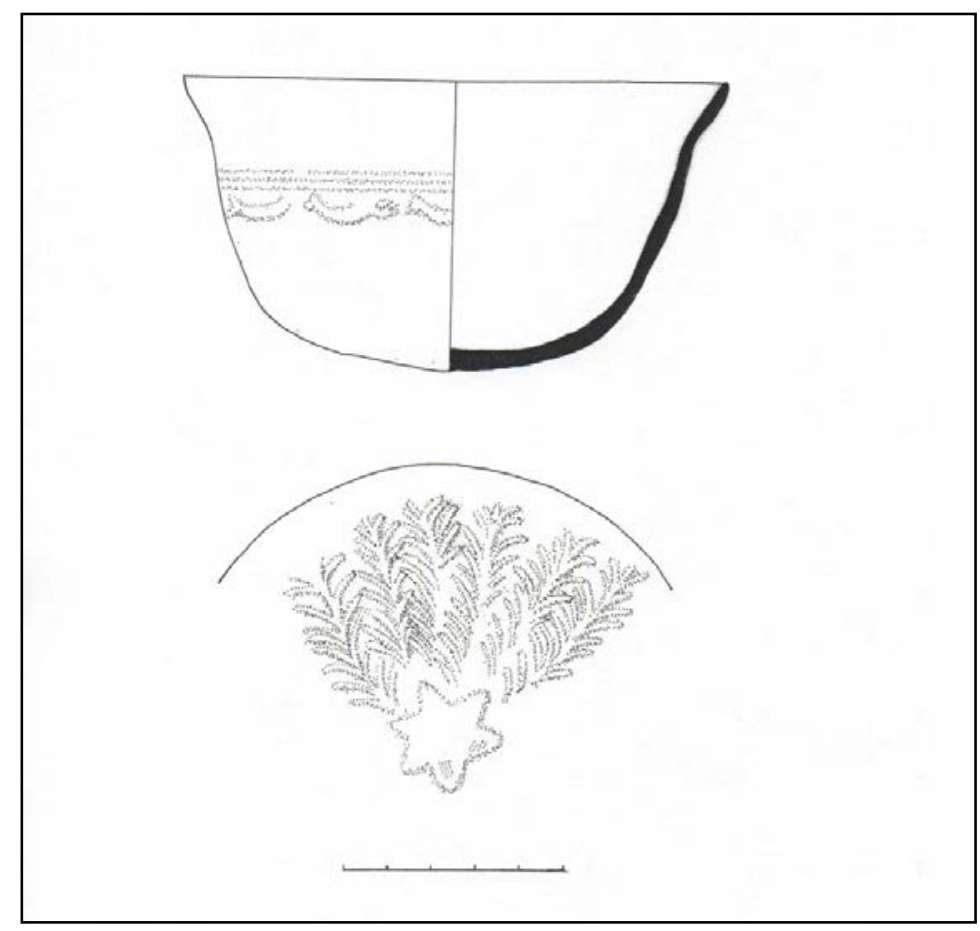

\section{Şekil 1}

2. Env. No: 611, kazı no: T.H. 81.53, resim 2a, 2b, şekil 2

Buluntu Yeri: Tille Höyük, 8736 no'lu açma

Müzeye geldiği gün: 20.06.1981

S: kırmızımsı kahverengi sır yer yer dökülmüştür

T: pembemsi devetüyü hamurlu, sık, ince, katkısız, sert

Ö: h: $6.4 \mathrm{~cm}$ (iç h: 5.8), k: ağız: 0.3-0.6cm, ç: $12 \mathrm{~cm}$

Kâsenin Durumu: Gövde ve kenarda yapıştırılmış çatlak ve kırıklar vardır.

Biçim: Yuvarlak dipli, dışa doğru genişleyen yayvan bir kâsedir. Kenar kısmı ortasından itibaren dudağa doğru kısmen düz bir biçimde dışa açılmaktadır.

Bezeme: Kenar kısmının altındaki ince bordür çizgisi, buradaki keskin çark izleriyle karışmış olup özelliğini yitirmiştir. Gövde üzerinde kabarık madalyon 
halkasından başlamak üzere dört adet palmiye ve bunların arasında dört adet akantus yaprağı yer almaktadır. Madalyon bezemesi olarak üçgenimsi dört geniş yaprağın arasında damla biçimli ince yaprakların bulunduğu bir kısmı silik olan bir çiçek rozeti yer almaktadır.

\section{Karşılaştırma}

Biçim: Cornell 1997: PI. 2: MB 15, Gerber 1996, Abb. 1, 11; Kramer 2004, Tafel 82, ESA 82; gövde bezemesi: Cornell 1997: PI. 2: MB 15, 16, 17; Christensen 1971: fig. 50; 30- 34; Waage 1948, fig.12: 15; madalyon bezemesi: Anlağan 2000: 154, 15

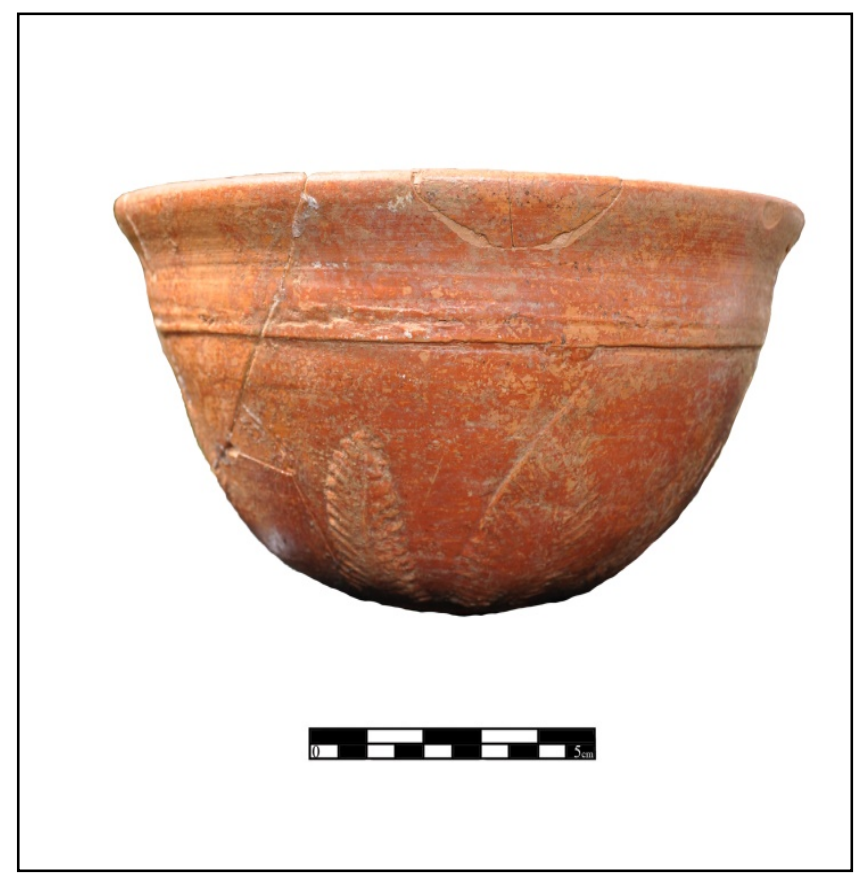

Resim 2a 


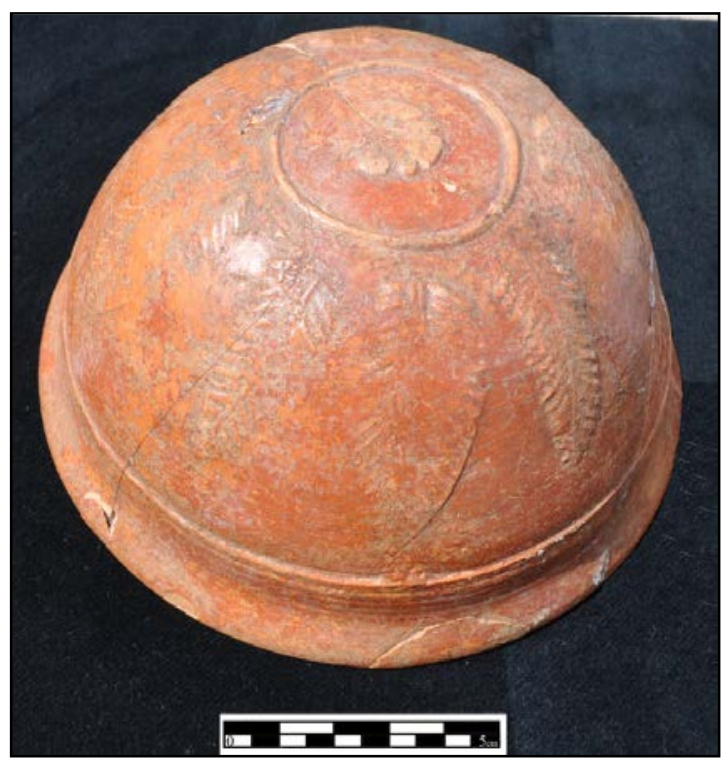

Resim 2b

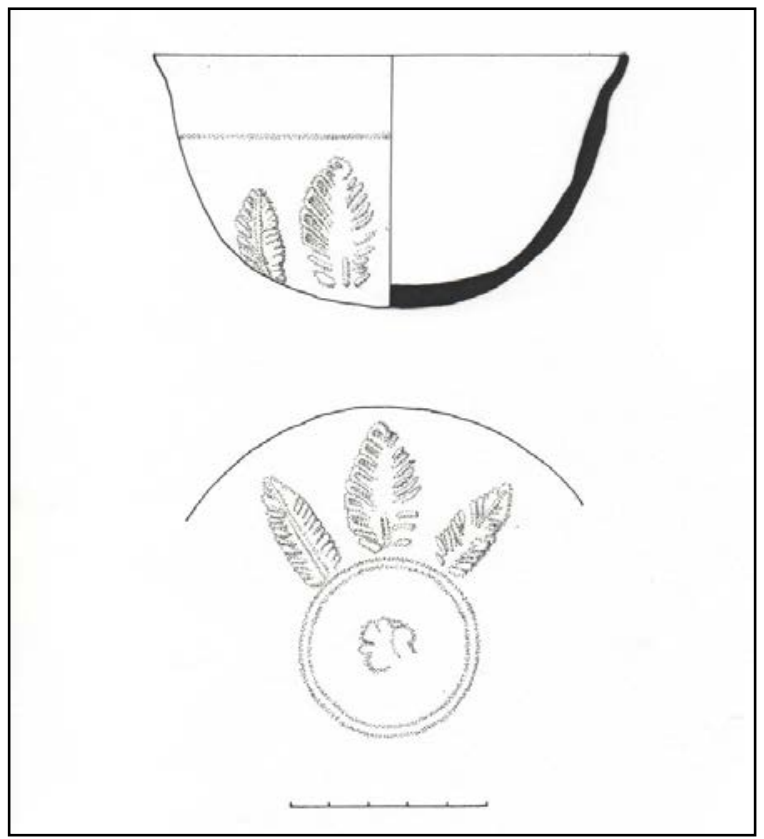

Şekil 2

Adıyaman Üniversitesi Sosyal Bilimler Enstitüsü Dergisi, Yıl: 8, Sayı: 23, Ağustos 2016 
3. Env. no. 4544, resim 3a, 3b, 3c, şekil 3

Buluntu Yeri: Adıyaman civarı

S: Koyu kırmızı kahverengi, yer yer dökülmüş, mat

T: Açık devetüyü, soluk hamurlu, sık, ince, katkısız

Ö: h: $5.6 \mathrm{~cm}$ (iç: $5.3 \mathrm{~cm}$ ) , a.ç: $12.1 \mathrm{~cm}, \mathrm{k}: 0.2-0.3 \mathrm{~cm}$

Kâsenin Durumu: Gövde üzerinde yapıştırılmış kırık ve çatlaklar, dudak kısmında küçük kırıklar, kenarda çark izleri vardır.

Biçim: Düz dipli, dışa doğru düz bir şekilde genişleyen yayvan bir kâsedir. Kenar kısmı dudağa doğru şişkince açılmaktadır.

Bezeme: Çok alçak kabartma şeklindeki bezemeler yer yer seçilememektedir. Kâsenin orta kısmının biraz altında kabartma ince bir çizgi vardır. Bu çizgi kâse üzerindeki bezemeleri iki gruba ayırmıştır. Üstte, kenar kısmında on adet yunus balığı peş peşe sıralanmıştır. Kabartma çizginin altında birbirinin boşluğuna gelecek şekilde iki sıra halinde üstte iki kulplu ince kadeh biçimli ayağı olan dokuz adet kantharos, altta dokuz adet ionik biçimli mimari bir element olasılıkla bir altar (resim 3c) yer almaktadır. Dipte iç içe biri büyük diğeri küçük iki ince çizgi madalyon bölümünü belirlemiştir. Madalyon bezemesi yoktur.

\section{Karşılaştırma}

Biçim: Cornell 1997: PI. 3: MB 27; Weinberg 1992: 18, fig. 7; Kraus 1951: 12, fig. 2; Yunuslar: Christensen 1971: fig. 55: 84 ve fig. 62: 20; Jones 1950: 138: 305; 142: C, Gövde Bezemesi: altar: Cornell 1997, 411: PI. 3: MB 44; Kraus 1951: Abbildung 5: 2, no. 16; Weinberg 1992: 16, fig. 4 (Kraus'un (1951, 12, dipnot 94) makalesindeki aynı kâse, Waage (1948 fig. 15: 2-6, 9 altar veya sütun kalıntıları); Christensen 1971: fig. 48: 1 


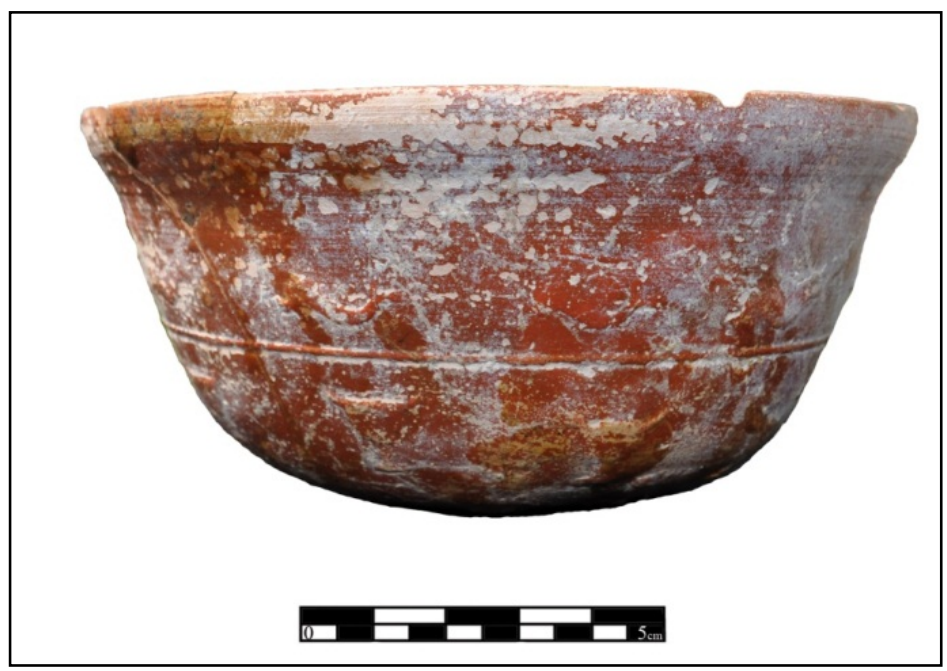

Resim 3a

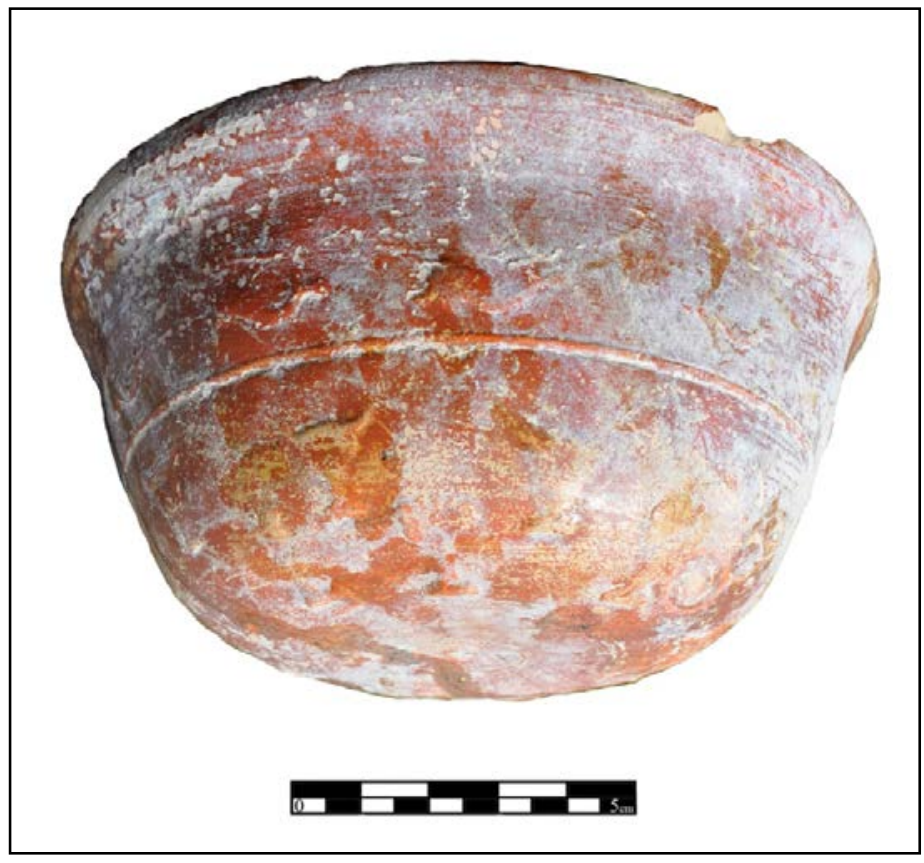

Resim 3b

Adıyaman Üniversitesi Sosyal Bilimler Enstitüsü Dergisi, Yıl: 8, Sayı: 23, Ağustos 2016 


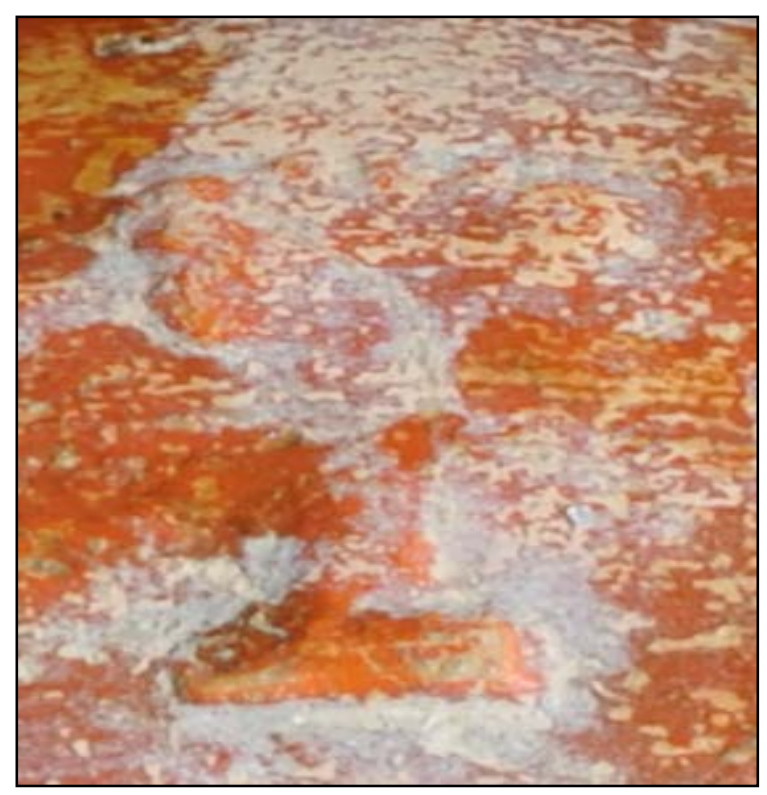

\section{Resim 3c}

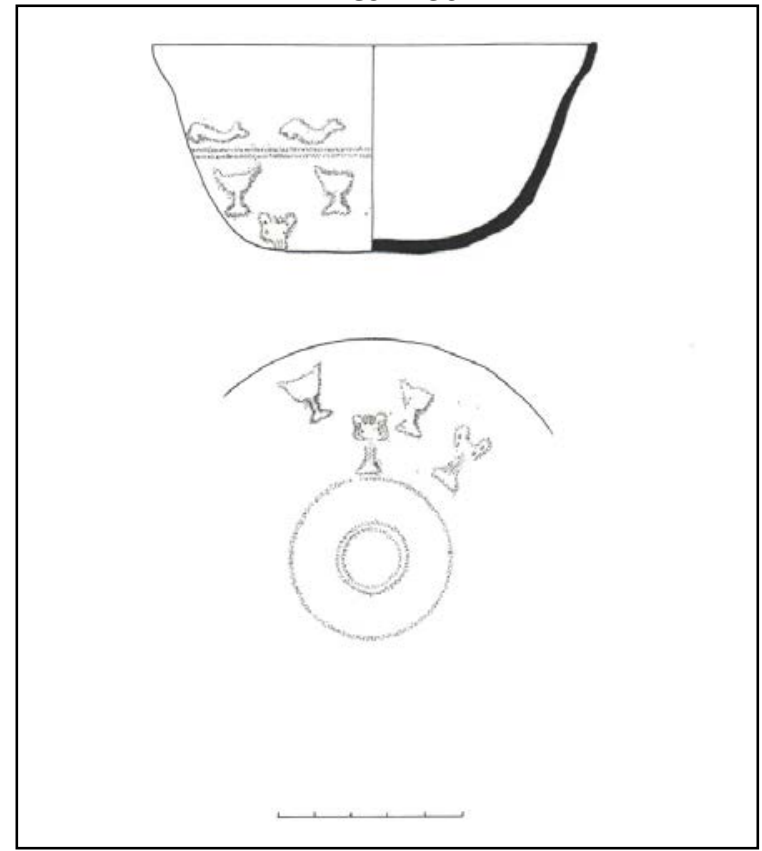

Şekil 3

4. Env. No. 4346, resim 4a, 4b, şekil 4

Adıyaman Üniversitesi Sosyal Bilimler Enstitüsü Dergisi, Yıl: 8, Sayı: 23, Ağustos 2016 
Buluntu Yeri: Adana civarı

S: Açık kırmızı-kahverengi

T: Açık devetüyü hamurlu, ince, sık, katkısız

Ö: h: $4.8 \mathrm{~cm}$ (iç: $4.2 \mathrm{~cm}$ ), a.ç: $12.4 \mathrm{~cm}, \mathrm{k}: 0.2 \mathrm{~cm}-0.6 \mathrm{~cm}$

Kâsenin Durumu: Dudak kısmında küçük bir kırık, yüzeyde aşınma ve hafif kireçlenme vardır. Biçim: Düz dipli dışa doğru genişleyen yayvan bir kâsedir. Kâsenin kenar kısmı dudağa doğru genişlemiştir. Kâsenin yüksekliği her yerde aynı değildir. Kenar kısmı bir tarafta diğer tarafına göre daha düzdür. Bezeme: Kenar kısmında yoğun çark izleri vardır. Çark izleri bazı yerlerde kenardan gövdeye geçişteki kabartma çizginin üzerine çıkmıştır. Gövde üzerinde dipten itibaren, orta omurgası belirli karşılıklı duran dört adet palmiye yaprağı ve bu yaprakların arasında, kâsenin üst kısmında yatay olarak verilmiş birer küçük horoz figürü bulunmaktadır. Dipte ise biri küçük biri büyük iç içe iki kabartma çizgi vardır, madalyon bezemesi yoktur.

\section{Karşılaştırma}

Biçim: Kramer 2004: Tafel 82: ESA 80; Taş 2010: fig.41, K15; gövde bezemesi: palmiye: Kramer 2004: Tafel 83: ESA 92; Waage 15: 28; Christensen 1971: fig. 51: 45a, b; Crowfoot 1957: fig.63, 22; Yıldız 2006, Levha 59, 423; Taş 2010: fig.41, K15 

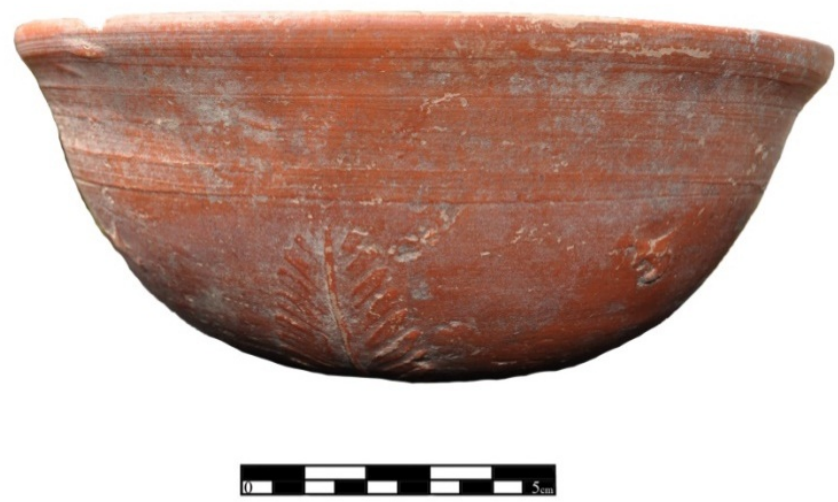

Resim 4a

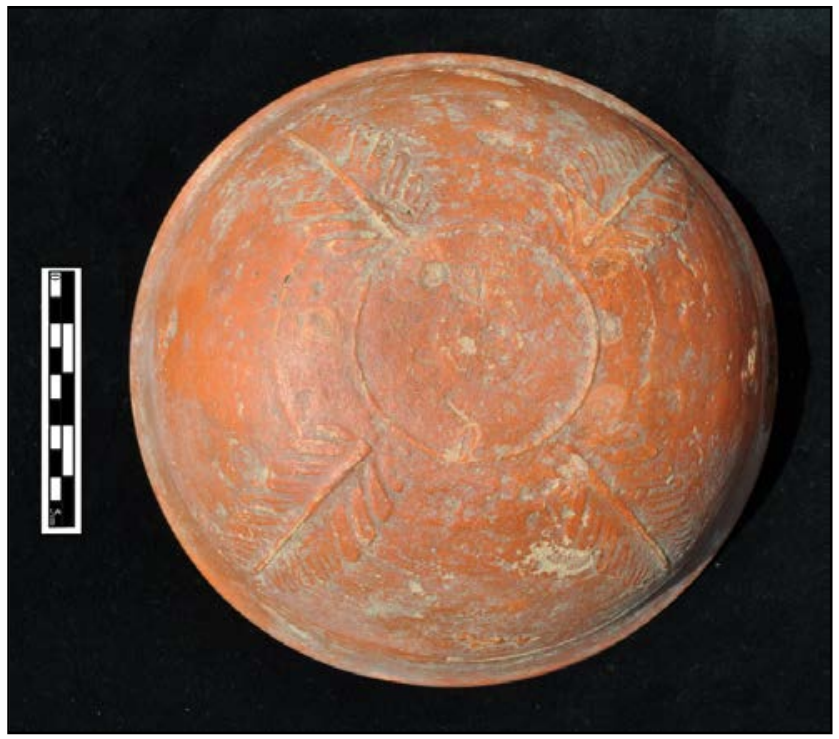

Resim 4b

Adıyaman Üniversitesi Sosyal Bilimler Enstitüsü Dergisi, Yıl: 8, Sayı: 23, Ağustos 2016 


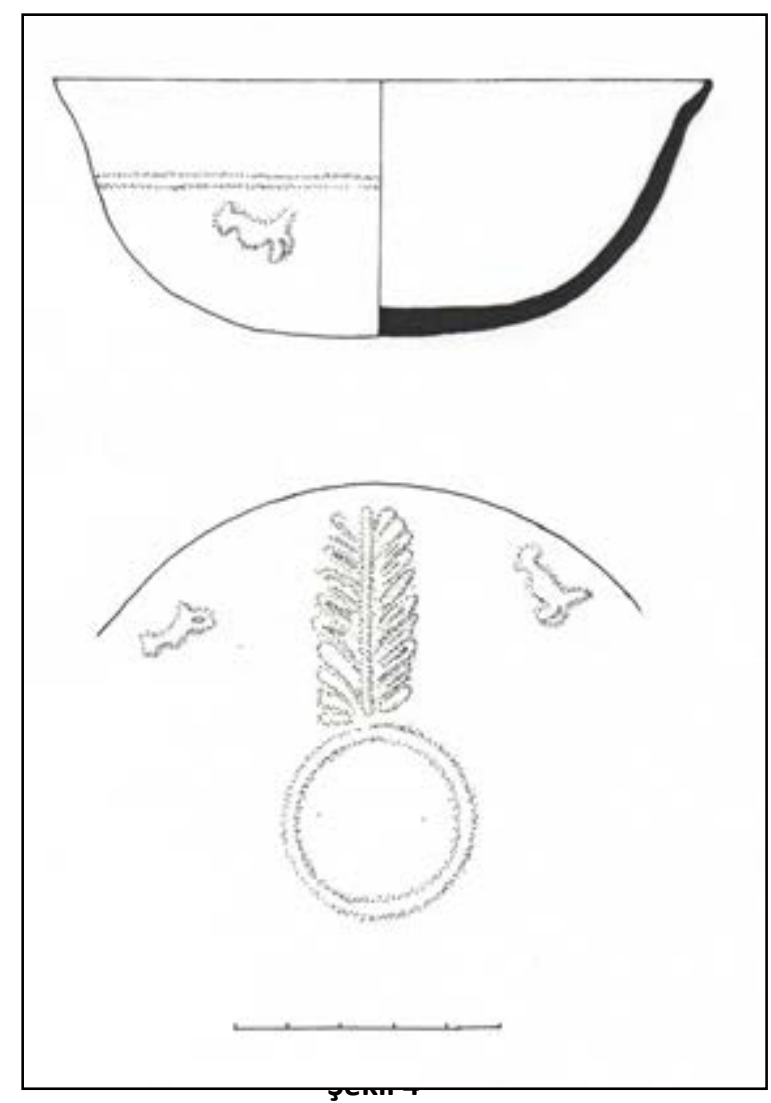

5. Env. No. 4373, resim 5a, 5b, 5c, şekil 5

Buluntu Yeri: Adana civarı

S: kiremit kırmızısı renkte, yer yer dökülmüş, mat

T: açık devetüyü hamurlu, sık, ince, katkısız

Ö: h: $4.8 \mathrm{~cm}$ (iç h:4.1cm), a.ç: $12.4 \mathrm{~cm}, k: 0.3 \mathrm{~cm}$ ( ağız)

Kâsenin Durumu: üç parça yapıştırılmış, iç kısmı ve kâsenin yarısına yakın bir bölümü tamamen kireç kaplıdır.

Biçim: Dışa doğru genişleyen yayvan bir kâsedir. Kenar kısmı da düz bir biçimde dışa doğru açılmıştır. 
Bezeme: Kenar kısmının altında kabartma bir çizgi vardır. Gövde üzerinde eşit aralıklarla yerleştirilmiş beş adet palmet motifi yer almaktadır. Palmetlerin tabanını uçları içe kıvrılmış iç bükey kabartma bir çizgi oluşturur. Bu çizginin üzerinde ortadaki tepe yaprağı düz, diğerleri dışa eğimli altı yapraklı palmet motifi yer almaktadır. Palmetlerin arasında üstte iki adet "dalga" veya "koşan köpek" olarak anılan tepesinde bir spiral bulunan üçgen bezemesi ve altta bunların arasında kadeh denilen pütürlü kısmı ile oval ince bir meşe palamutu motifi yer almaktadır. Dipte iç içe iki kabartma halka vardır. Madalyon bezemesi yoktur.

\section{Karşılaştırma}

Biçim: Jones 1950: PI. 189; 341; Christensen 1971: fig 46: 93; koşan köpek motifi: Waage 1948: fig. 9: 22; fig. 11: 9; fig.16: 19; Christensen 1971: fig. 14: 124; Kossatz 1990, 13, M 28, Tafel 23, Tafel 31; Laumonier 1977: PI.12: 5605, PI. 16: 9300, PI. 18, 37, 41, 44, 47, 48, 54 ve diğer levhalardaki örnekler; palmet: Waage 1948: fig. 16: 10; Crowfoot 1957: fig. 63: 23; Reisner 1924: 72e

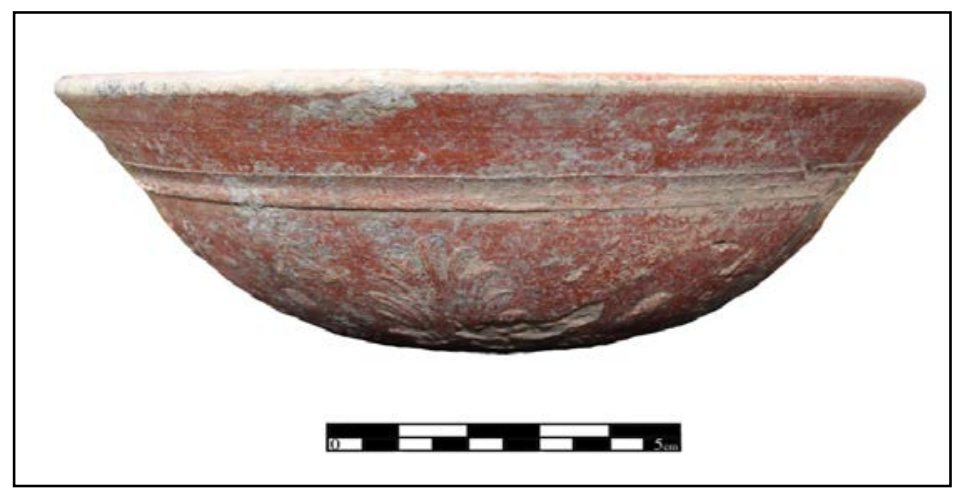

\section{Resim 5a}




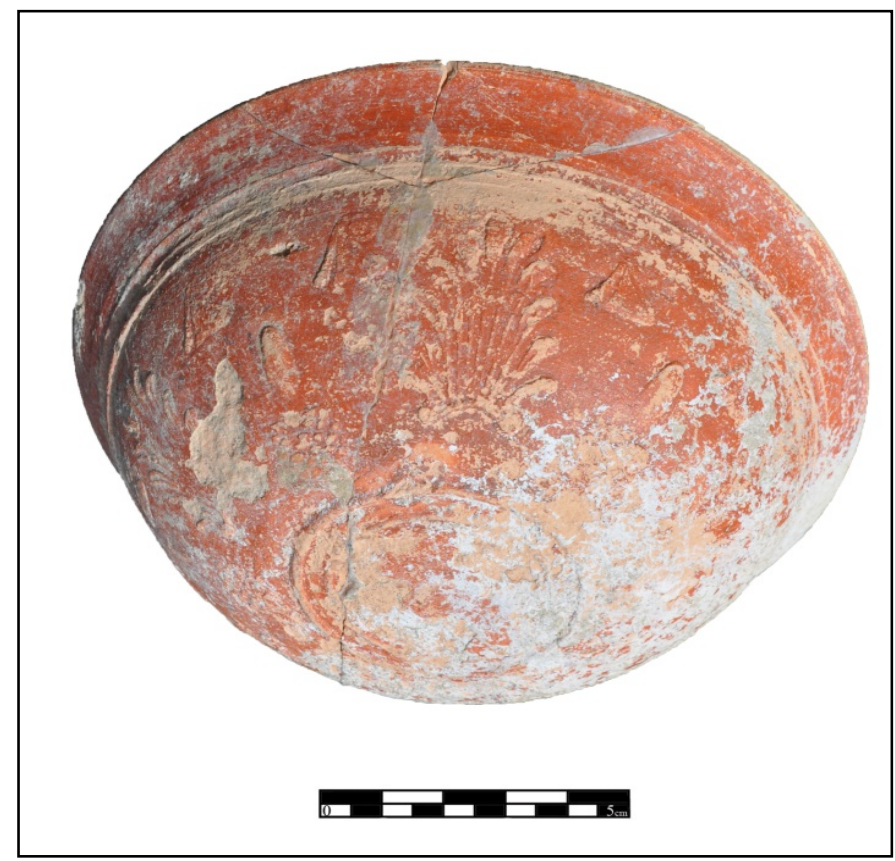

Resim 5b

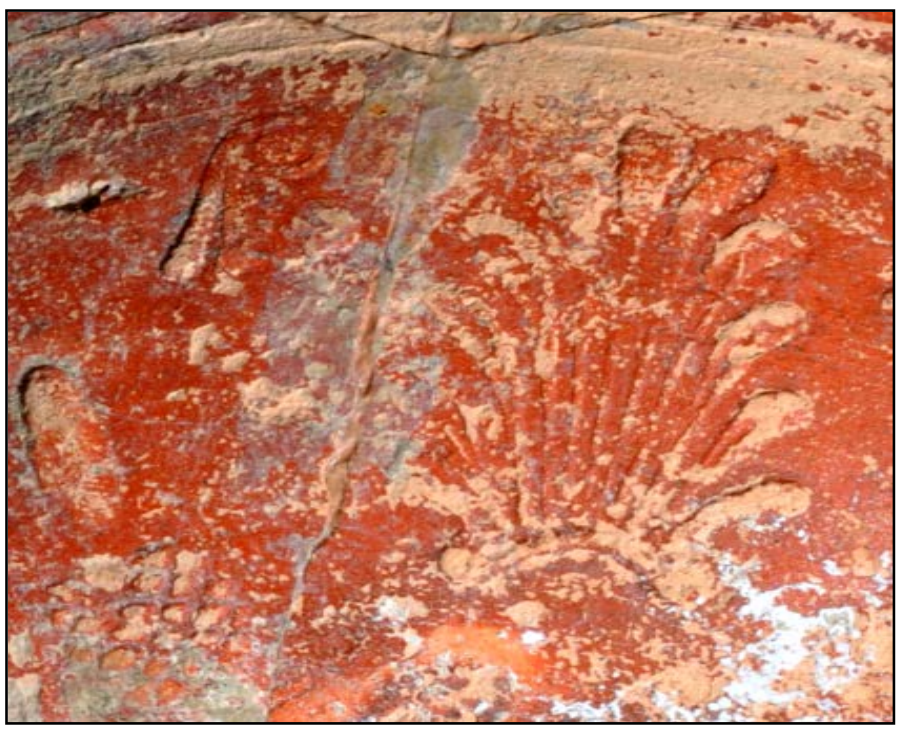

Resim 5c

Adıyaman Üniversitesi Sosyal Bilimler Enstitüsü Dergisi, Yıl: 8, Sayı: 23, Ağustos 2016 


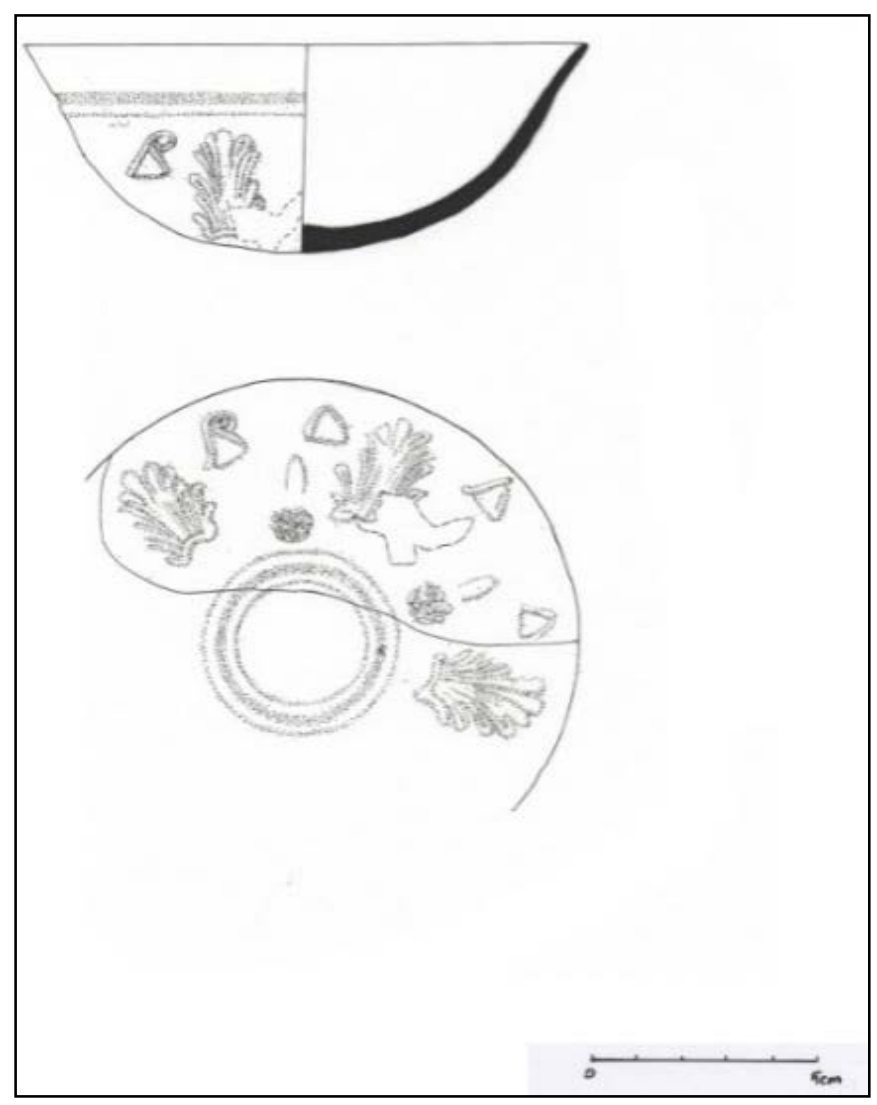

Şekil 5

\section{Teşekkür}

Bu çalışmam için Kültür ve Turizm Bakanlığı Kültür Varlıkları ve Müzeler Genel Müdürlüğüne ve Adıyaman Müzesi Müdürü Sayın Fehmi Eraslan ve Müze çalışanlarına teşekkür ederim. 


\section{KAYNAKÇA}

Anlağan, T. (2000). Sadberk Hanım Müzesi Kalıplı Kâseler ve Kabartmalı Kaplar, İstanbul.

Bounni, A. (1978). Bounni, A, E. Legarce, J. Legarce, N. Saliby, Rapport prelimaniere sur la deuxieme campagne de fouilles 1776, a Ibn Hani, in Syria Tome 55, 3-4, Persee, Syria.

Christensen, A. P. (1971). Hama, Fouilles et Recherches 1931-1938 III, 2 Les Poteries Hellenistiques et les Terres Sigillees Orientales, Kobenhavn.

Cornell, L. (1997). "A Note on the Molded Bowls" Tel Anafa II, i, The Hellenistic and Roman Pottery, Ann Arbor. 407- 416

Crowfoot, J. W. (1957). Crowfoot G., Crowfoot J. and Kenyon K. The Objects from Samaria Sebaste 3. London: Palestine Explaration Fund.

Çorbacı, H. (2007). Mersin Müzesi'nde Bulunan Megara Kâseleri, Ç.Ü.Sosyal Bilimler Dergisi, Cilt 16 Sayı 2, Adana. 169-186

Çorbacı, H. (2012). “Tarsus Müzesi Hellenistik ve Hellenistik-Roma Dönemi Kalıp

Yapımı Kâseleri", Arkeoloji ve Sanat Dergisi sayı 140. 75-90

Dragendorf, H. (1895). Terra Sigillata, Bonn.

Farnel, L. R. (1896). The cults of the Greek states, Oxford.

French, D. (1982). Tille 1981, IV Kazı Sonuçları Toplantısı, 1982, Ankara. 415-418

French, D. ( 1984). Tille 1983, VI Kazı Sonuçları Toplantısı, 1984, Ankara. 245-258

Genç, A. P. T. (2005). Hitit Seramikleri, Yayımlanmamış Yüksek Lisans Tezi, SDÜ Sosyal Bilimler Enstitüsü, Isparta.

Gerber, C. (1996). "Die Umgebung des Lidar Höyük von hellenistischer bis frühislamischer Zeit". Continuity and change in Northern Mesopotamia from the Hellenistic to the early Islamic period, ed. K. Bartl and S.R. Hauser, Berlin.

Hayes, J.W. (1985/1986). "Sigillate Orientali", Enciclopedia dell'arte antica, classica e orientali, Atlante delle forme ceramice, II, Roma. 
Hayes, J.W. (2008). Roman Pottery. Fine Ware Imports. Athenian Agora XXXII. Princeton NJ.

Hellström, P. (1965). Labraunda, Pottery of Classical and Later Date, Terracotta Lamps and Glass, Swedish Excavations and Researches Vol II. Part 1. Lund. 19-23

Hesiodos, Works and Days, (1914). (çev. Hugh G. Evelyn-White) Cambridge, London.

Iliffe, J.H. (1936). Sigillata Wares in the Near East A List of Potters' Stamps, QDAP 6, 9, Vol. 1.

Jackson, H-Tidmarsh J, (2013). Pottery Imports to Hellenistic Jebel Khalid on the Euphrates, Networks in the Hellenistic World, BAR 2539. 329-339

Johnson, B. L. (2008). Ashkelon 2, Imported Pottery of the Roman and Late Roman Periods, Harvard.

Jones, F. F. (1950). (ed, H.Goldman) The Hellenistic and Roman Periods Excavations at Gözlükule, Tarsus I, New Jersey, Princeton University Press.

Kenrick, P.M. (2013). "Pottery Other Than Transport Amphorae”, Excavations at Zeugma, Conducted by Oxford Archaeology, Edited by William Aylward

Kenyon, K. M. (1957). J. W. Crowfoot - G. M. Crowfoot, The Objects from Samaria-Sebaste, III, London.

Kossatz, U. (1990). Funde aus Milet. Teil 1. Die Megarischen Becher, Walter de Gruyter, Berlin.

Kramer, N. (2004). Gindaros, Geschichte Und Archaeologie einer Siedlungen im Nordwestlichen Syrien von hellenistischer bis in frühbyzantinische Zeit, Rahden Westf.

Kraus, T. (1951). Megarische Becher im Römisch-Germanischen Zentralmuseum zu Mainz, Mainz. 
Lapp, P. W. (1961). Palestinian Ceramic Chronology 200 B.C. - A.D. 70, American Schools of Oriental Research, New Haven.

Laumonier, A. (1977). La céramique hellénistique à reliefs 1. Ateliers "loniens", Délos XXXI, Paris.

Lehmann, G. (1998). Trends in the Local Pottery Development of the Late Iron Age and Persian Period in Syria and Lebanon, ca. 700 to 300 B. C. Bulletin of the American Schools of Oriental Research, No . 311.

Malfitana, D. (2002). Eastern terra sigillita wares in the Eastern Mediterranean. Notes on an initial quantitative analysis. In Lyon, Maison de l'Orient et de la Méditerranée Jean Pouilloux.

Malfitana, D. (2006). Malfitana D. Lund J ,P. Jeroen, Rhosica vasa mandavi: Towards the Identificationof a majör Ceramic tableware Industry of the easter Mediterranean: eastern sigillata: Archeologia Classica. 2006 vol. 57 , n.s 7.

Kenrick, P.M. (2013). "Pottery Other Than Transport Amphorae”, Excavations at Zeugma, Conducted by Oxford Archaeology, Edited by William Aylward Plinius, Naturalist Historia. Ed. H. Rackham, 1961, London.

Reisner, G. A. (1924). Harvard Excavations at Samaria, 1908-1910. Cambridge Harvard University Press.

Slane, K. W. ( 1997). Slane, K. W. and Berlin, A. Tel Anafa II, The Hellenistic and Roman Pottery, ed. Sharon, C., Ann Arbor, MI.

Taş, H.Y. (2010). Adana Müzesi'nden Kalıp Yapımı Kâseler, Adnan Menderes Üniversitesi Sosyal Bilimler Enstitüsü Yayınlanmamış Doktora Tezi, Aydın.

Vessberg, O. (1956). O. Vessberg - A. Westholm. The Hellenistic and Roman Periodes in Cyprus. The Swedish Cyprus Expedition III, 4, Stockholm.

Waage, F. O. (1948). Ceramics and Islamic Coins, Antioch-on-the-Orontes IV 1, Wisconsin. 
Weinberg, S. S. (1992) ."Molded Bowls from Tel Anafa and elsewhere", Muse 26. $12-20$

Yıldız, V. (2006). Tarsus Cumhuriyet Alanı Kazısında Bulunan Doğu Sigillata A Grubu Seramikleri, Selçuk Üniversitesi, Yayımlanmamış Yüksek Lisans Tezi, Konya.

Zahn, R. (1904). Zahn R. Th. Wiegand, H. Schrader. Priene. Ergebnisse der Ausgrabungen 1895-1898, Berlin.

İnternet kaynakları: https://tr.wikipedia.org/wiki/Artemis. 2016. https://tr.wikipedia.org/wiki/Karun_Hazinesi. 2016.

\section{EXTENDED ABSTRACT}

\section{Introduction}

Molded bowls (Megarian Bowls), which were commonly used in the Mediterranean Basin during the Hellenistic Period, are drinking vessels substituting for the kantharos of the Classical Period. Made in molds with clay, having almost hemispherical shape with no handle and foot, these bowls were embossed on the outside. Being an imitation of metalwork, these relief bowls were painted either in black, red or brown tones to give them metal effect. In the midst of the $2^{\text {nd }}$ century $B C$, a new technique and thus new types of vessels emerged when Eastern potters glazed the exterior surface of the bowls with red completely. These vessels, which were popular in the Late Hellenistic and Early Roman periods, were named Terra Sigillata. Megarian bowls during these periods kept their hemispherical shape partially and survived at smaller scale, shallowly and with less decoration.

Vessels named Terra Sigillata, which are red glazed, shaped in molds, decorated in relief or are undecorated, are examined under two groups as Eastern and 
Western Sigillata. Western Sigillata wares are common in Italy, France, Spain and Germany while Eastern Sigillata wares are common in Asia Minor, Syria, Cyprus and Egypt.

\section{Terra Sigillata}

These vessels, which are thinly red-glazed, decorated on the surface, well-baked and in various forms, are the imitations of their metal works with their sharpedged shapes (Dragendorf, 1895: 19). Dragendorf categorized this type as Western Sigillata. Kenyon (1957: 281, 282), who conducted researches in Samaria, categorized the Eastern Sigillata (ES). Kenyon used the terms Eastern Sigillata A (ESA) for the Late Hellenistic and Early Roman Pergamen wares which Waage (1948: 4) named Antiochian Sigillata wares previously, Eastern Sigillata B (ESB) for Samos wares, and Eastern Sigillata C (ESC) for Çandarlı wares. The group of Eastern Sigillata A mainly consists of plates, vessels and bowls.

Kenyon (1957: 281 et al.) grouped the Megarian Bowls in Samaria in form 20. These bowls, which are a continuation of the molded and hemispherical bowls of the Hellenistic Period (Megarian Bowls), are found in Tarsus, Antakya, Hama and other Syrian-Palestinian settlements in great quantities (Hayes, 2008: 16). Recent findings in the Levant show that these wares dated to shortly before 150 BC as Waage (1948: 25) suggested for Antiochian ESA. In some centers, production went on until through $3^{\text {rd }}$ century AD (Kramer, 2004: 174, footnote 373).

\section{Method}

According to the inventory researches carried out about five bowls in Adıyaman Museum by permission of The General Directorate of Cultural Heritage and Museums of The Ministry of Culture and Tourism as well as of Adıyaman 
Museum Directorate, one of the bowls comes from Tille Höyük while others, having been purchased, come from the vicinities of Adana and Adıyaman. Apart from the drawing and photography of the bowls, their features of soil texture and its color, color features of their glazing, their sizes and descriptions have been catalogued. The bowls were compared and contrasted with both each other and other samples with similar features. Their possible production centers and dates were sought to be identified.

\section{Discussion}

The largest ceramic production center in Syria was Antioch in the Hellenistic Period (Kramer, 2004: 137). Antiochian wares are widespread in this region because Syria and Palestine were in close trade relations during this period. A majority of the late type of the Megarian bowls were found in the very northern part of Antioch (Weinberg, 1992: 19). Crowfoot (1957: 272) stated in his research that Megarian bowls in Samaria were imported from the Antiochian metropolis while Kramer (2004: 179) indicated that Gindaros ESA findings share structural similarities to a large extent with Antiochian samples. According to Malfitana's research on the spread of the Eastern Terra Sigillata in the Eastern Mediterranean, ESA findings in Syria center around the northwestern part of Syria (Malfitana, 2002: 147). No certain source center about the widespread and production of the ESA has been identified so far. Chemical and scientific analyses show that possible production center of the ESA covers the eastern coast of Cilicia or Hatay coast, or probably the northern part of İskenderun (Alexandretta) in particular in our day (Hayes, 2008: 13).

Since bowls Number 1 and 2 in the catalogue have the characteristics of both the early and late periods, these bowls can be described as samples representing transition from early types to late ones. Bowl no. 2 comes from Tille Höyük. French (1982: 417) dated the bowls of the Hellenistic layer to $1^{\text {st }}$ 
century $B C$ and $1^{\text {st }}$ century $A D$ in average. A bowl similar to no. 2 was found in Lidar Höyük, which Gerber (1996: 304) described as imported product. The sample of both the shape and decoration of the column of the bowl no. 3 is the same with the bowl in Mainz and with the one compared with the Antiochian sample and dated by Kraus (1951: 12 ) to the second half of the $1^{\text {st }}$ century BC. The one similar to the bowl no. 4 is present in Adana Museum (Taş, 2010: fig. $41, \mathrm{~K} 15)$. The shape of the bowl no. 5 is relatively broad and shallow and is flatedged. Decoration motifs of the bowl share similarities with the ones in Antakya.

\section{Conclusion}

Color features of the bowls, just like their non-micaceous and mere structural features, resemble the bowls in Antioch, which is believed to have been the largest ceramic production center in the Northern Syria-Palestine Region. These bowls under investigation could be dated around to the $1^{\text {st }}$ century $B C$ in accordance with their characteristics as the late samples of the Megarian bowls. 